\title{
Continuing the paradigm shift in the treatment of idiopathic membranous nephropathy
}

\section{Antoine Barbari}

I read with interest the recent Review by P. Ruggenenti et al. (Treatment of membranous nephropathy: time for a paradigm shift. Nat. Rev. Nephrol. 13, 563-579; 2017) ${ }^{1}$. The observed inconsistency in therapeutic responses with conventional therapies directed at $\mathrm{T}$ cells and $\mathrm{B}$ cells ${ }^{2}$, as well as the superior complete remission rates (53\%) achieved with rituximab in patients with recurrent membranous nephropathy post-transplantation ${ }^{3}$ compared to rates in those with native kidneys (13.6-19\% $)^{4,5}$, highlight the important role of T cells in autoimmune kidney diseases ${ }^{6}$ and the likely added value of T cell-targeted therapies in addition to anti-CD20 monoclonal antibody therapy in increasing remission rates. These observations imply the existence of different immunopathogenic signatures - primarily B cell-mediated pathways with a component of $\mathrm{T}$ cell help $\mathrm{p}^{6,7}-$ in addition to distinct mechanisms of autoantibody and alloantibody secretion by different $B$ cell lineages, for example, by $\mathrm{CD} 20^{+}$activated $\mathrm{B}$ cells in spleen and lymph nodes, $\mathrm{CD} 19^{+} \mathrm{CD} 20^{-}$plasmablasts and short-lived plasma cells in blood, and CD19CD $20^{-} \mathrm{CD} 38^{+} \mathrm{CD} 138^{+}$long-lived memory plasma cells located in the bone marrow and ectopically in the inflamed kidney ${ }^{8}$. These non-proliferating long-lived memory plasma cells produce considerable amounts of IgG autoantibodies and alloantibodies, and provide the basis for humoral memory and refractory autoimmune diseases ${ }^{7-10}$.

As pointed out by Ruggenenti et al., the lack of CD19 and CD20 expression by longlived memory plasma cells renders these cells resistant to depletion by anti-CD20 monoclonal antibodies ${ }^{1,5,9}$. This resistance might explain the limited rate of sustained complete remission and recovery achieved by rituximab in patients with idiopathic membranous nephropathy, despite successful depletion of circulating B cells ${ }^{4,5,10-12}$. I agree that use of plasma-cell-depleting therapies, such as the newly introduced anti-CD38 monoclonal antibodies and the less specific proteasome inhibitors with anti-B cell and anti-T cell activities ${ }^{13}$, might offer novel therapeutic alternatives for patients with idiopathic membranous nephropathy, at least in those who are refractory or only partially respond to combined conservative treatment plus rituximab therapy ${ }^{12}$. Whether new second and third generation anti-CD20 monoclonal antibodies can achieve higher rates of sustained complete remission than rituximab ${ }^{1}$ remains to be determined, but such agents do not target long-lived memory plasma cells ${ }^{8,14}$. Surprisingly, another anti-CD20 monoclonal antibody, ofatumumab, failed to demonstrate superiority over rituximab as salvage chemotherapy in patients with relapsed or refractory diffuse large B cell lymphoma ${ }^{15}$. New immunologic biomarkers are needed to help to identify patients who are likely to respond to $\mathrm{T} \mathrm{cell}^{3}, \mathrm{~B}$ cell $^{7,8}$, or combination therapy ${ }^{12,14}$. In addition to measuring CD19 and CD20 (REFS 1,4,5,9,11), assessment of patients with membranous nephropathy should include measurement of the longlived memory plasma cell markers, CD38 and CD138, particularly in patients with relapsing or rituximab-resistant disease $\mathrm{7}^{7-10,12,14}$.
Antoine Barbari is at the Renal Transplant Unit, Rafik Hariri University Hospital, Bir Hassan, Beirut, Lebanon. barbariantoine@gmail.com doi:10.1038/nrneph.2017.134 Published online 25 Sep 2017

1. Ruggenenti, P., Fervenza, F. C. \& Remuzzi, G. Treatment of membranous nephropathy: time for a paradigm shift. Nat. Rev. Nephrol. 13, 563-579 (2017).

2. van den Brand, J. A.J. G. et al. Safety of rituximab compared with steroids and cyclophosphamide for idiopathic membranous nephropathy. J. Am. Soc. Nephrol. 28, 2729-2737 (2017).

3. Grupper, A. et al. Recurrent membranous nephropathy after kidney transplantation: treatment and long-term implications. Transplantation 100, 2710-2716 (2016)

4. Ruggenenti, P. et al. Anti-phospholipase A2 receptor antibody titer predicts post-rituximab outcome of membranous nephropathy. J. Am. Soc. Nephrol. 26 2545-2558 (2015).

5. Dahan, K. et al. Rituximab for severe membranous nephropathy: a 6-month trial with extended follow-up. J. Am. Soc. Nephrol. 28, 348-358 (2017).

6. Suárez-Fueyo, A. et al. T cells and autoimmune kidney disease. Nat. Rev. Nephrol. 13, 329-343 (2017).

7. Hoffman, W. Lakkis, F. G. $\&$ Chalasani, G. B cells, antibodies, and more. Clin. J. Am. Soc. Nephrol. 11, 137-154 (2016).

8. Hiepe, F. \& Radbruch, A. Plasma cells as an innovative target in autoimmune disease with renal manifestations. Nat. Rev. Nephrol. 12, 232-240 (2016).

9. Henrik, E. M. et al. A unique population of lgGexpressing plasma cells lacking CD19 is enriched in human bone marrow. Blood 125, 1739-1748 (2015).

10. Clatworthy, M. R. Targeting B cells and antibody in transplantation. Am. J. Transplant. 11, 1359-1367 (2011).

11. Ronco, P. \& Debiec, H. Pathophysiological advances in membranous nephropathy: time for a shift in patient's care. Lancet 385, 1983-1992 (2015).

12. Barbari, A. et al. Bortezomib as a novel approach to early recurrent post-kidney transplant membranous glomerulonephritis refractory to combined conventional-rituximab therapy. Exp. Clin. Transplant. 15, 350-354 (2017).

13. Lemy, A., Toungouz, M. \& Abramowicz, D. Bortezomib: a new player in pre- and post-transplant desensitization? Nephrol. Dial. Transplant. 25, 3480-3489 (2010).

14. Barbari, A. Pre- and posttransplant refractory idiopathic membranous glomerulonephritis: the forgotten potential culprit. Exp. Clin. Transplant. http://dx.doi.org/10.6002/ect.2017.0185 (2017).

15. van Imhoff, G. W. et al. Ofatumumab versus rituximab salvage chemo-immunotherapy in relapsed or refractory diffuse large B-cell lymphoma: the ORCHARRD study. J. Clin. Oncol. 35, 544-551 (2017).

Competing interests statement

The author declares no competing interests. 